\title{
Desempenho de ovinos mantidos com dietas com capim-elefante ensilado com diferentes aditivos ${ }^{1}$
}

\author{
José Nobre de Carvalho Junior ${ }^{2}$, Aureliano José Vieira Pires ${ }^{3,5}$, Fabiano Ferreira da Silva ${ }^{3,5}$, \\ Cristina Mattos Veloso ${ }^{3,5}$, Cristiane Leal dos Santos-Cruz ${ }^{3}$, Gleidson Giordano Pinto de Carvalho ${ }^{5}$
}

1 Projeto de pesquisa financiado pelo CNPq.

2 Programa de Pós-graduação em Zootecnia pela UESB, Itapetinga, BA.

${ }^{3}$ DTRA-UESB, Itapetinga, BA.

${ }^{4}$ Programa de Pós-graduação em Zootecnia - UFV, Viçosa, MG.

5 Pesquisador do CNPq.

RESUMO - Avaliaram-se os efeitos da adição de 15\% de casca de café, farelo de cacau ou farelo de mandioca, com base na matéria natural (peso/peso), à forragem verde de capim-elefante no momento da ensilagem sobre o consumo de nutrientes e o desempenho de 20 ovinos Santa Inês em confinamento. Os animais tinham 5 meses de idade, peso inicial de $22,27 \pm 3,24 \mathrm{~kg}$ e o peso final foi de $28,6 \pm 3,78 \mathrm{~kg}$. Utilizou-se um delineamento experimental inteiramente ao acaso, com quatro tratamentos e cinco repetições. Os tratamentos foram: capim-elefante ensilado sem aditivo ou ensilado com $15 \%$ de casca de café, farelo de cacau ou farelo de mandioca. A utilização da casca de café, do farelo de cacau e do farelo de mandioca na ensilagem de capim-elefante aumentou o consumo de matéria seca. Os maiores consumos de proteína bruta foram observados nas silagens contendo farelo de cacau e farelo de mandioca. Os consumos de fibra em detergente neutro foram semelhantes e o consumo de nutrientes digestíveis totais foi maior na silagem contendo farelo de mandioca. A conversão alimentar dos animais não foi afetada pela inclusão dos aditivos na ensilagem. A inclusão de farelo de mandioca na ensilagem de capim-elefante aumenta o ganho de peso (140,5 g/dia) em ovinos Santa Inês.

Palavras-chave: consumo, ensilagem, ganho de peso, nutrientes

\section{Performance of sheep fed diets with elephant grass ensiled with different addictives}

\begin{abstract}
The effects of the addition of 15\% of different addictives (coffee hulls, cocoa meal and cassava meal) to green elephant grass forage, in natural matter basis (weight/weight), at the ensilage moment on the consumption of nutrients and the performance of twenty Santa Inês sheep under feedlot system were evaluated. The animals had 5.0 months of age, initial weight of $22.27 \pm 3.24 \mathrm{~kg}$ and final weight of $28.6 \pm 3.78 \mathrm{~kg}$. The treatments were: $\mathrm{T} 1=$ elephant grass ensiled without addictive; $\mathrm{T} 2$ = elephant grass ensiled with 15\% coffee hulls; $\mathrm{T} 3$ = elephant grass ensiled with $15 \%$ cocoa meal; T4 = elephant grass ensiled with $15 \%$ cassava meal. The use of the addictives coffee hulls, cocoa meal and cassava meal in elephant grass ensilage increased the dry matter intake. The greatest crude protein intakes were observed with silage containing cocoa meal and cassava meal. Neutral detergent fiber intakes were similar, and the total digestible nutrients intake was higher in silage containing cassava bran. The feed conversion rate of the animals was not affected by the inclusion of addictives in ensilage. Diet containing elephant grass ensiled with cassava meal showed higher weight gain along the period and per day, however, no difference was observed in the feed conversion rate. The addition of cassava meal in ensilage of elephant grass provided weight gain of 140.5 g/day in Santa Inês sheep.
\end{abstract}

Key Words: ensilage, intake, nutrients, weight gain

\section{Introdução}

O uso de silagens de gramíneas tropicais é uma prática comum na produção de ruminantes no Brasil, como forma de utilização do excedente da produção forrageira do período chuvoso para reduzir o problema de escassez de alimento no período seco. Entre as gramíneas perenes, o capimelefante (Pennisetum purpureum, Schum.), tradicionalmente utilizado para corte em capineiras, tem se destacado como forrageira para ensilagem; seu uso é indicado principalmente por suas características de produção de matéria seca e seu valor nutritivo (Andrade \& Lavezzo, 1998). 
Entretanto, no momento ideal para o corte, o capim-elefante e as gramíneas em geral apresentam altos teores de umidade, baixas concentrações de carboidratos solúveis, características que influenciam negativamente o processo fermentativo, impedindo o rápido decréscimo do $\mathrm{pH}$ e permitindo a ocorrência de fermentações secundárias indesejáveis, o que prejudica a qualidade do produto preservado (McDonald, 1981; Lavezzo, 1993).

O uso de resíduos agroindustriais na alimentação, principalmente em sistema de confinamento, é fundamental quando o objetivo é reduzir o custo de produção (Garcia et al., 2000). Os resíduos da agroindústria podem apresentar características de alimentos fibrosos, como bagaço de canade-açúcar e palhadas, ou de alimentos concentrados, como polpa cítrica, casca e farinha de mandioca, caroço de algodão, casca de soja e farelo de arroz. Entretanto, dependendo da constituição da dieta, das características intrínsecas e da forma como é fornecido, determinado resíduo pode se comportar de forma distinta, concentrado ou volumoso.

A casca de café é um resíduo proveniente do beneficiamento do grão; o farelo de cacau, um resíduo da retirada da casca dos grãos pela lavagem, submetidos ao vapor e à torrefação e posteriormente à produção de manteiga ou chocolate; e o farelo de mandioca, um resíduo proveniente da lavagem da mandioca triturada para posterior produção da fécula.

Carvalho et al. (2006) evidenciaram que a utilização de 15\% de farelo de cacau na dieta total de ovinos não causa prejuízo ao desempenho.

Zeoula et al. (2003) observaram que a substituição do milho pela farinha de varredura não afetou o consumo e a digestibilidade dos nutrientes. Resultados semelhantes foram relatados por Souza et al. (2004) quando substituíram o milho por $25 \%$ de casca de café na dieta de ovinos.

O trabalho foi conduzido com o objetivo de avaliar o desempenho e o consumo de nutrientes em ovinos Santa Inês alimentados com rações contendo casca de café, farelo de cacau ou farelo de mandioca no capim-elefante ensilado.

\section{Material e Métodos}

O trabalho foi desenvolvido no Setor de Ovinocultura e no Laboratório de Forragicultura e Pastagem da Universidade Estadual do Sudoeste da Bahia, UESB, Campus Juvino Oliveira, em Itapetinga, Bahia, no período de novembro de 2005 a abril de 2006.

Na confecção da silagem, foi utilizado o capim-elefante (Pennisetum purpureum Schum.), cultivar Cameroon, proveniente de capineira já estabelecida. O capim foi cortado manualmente, rente ao solo, quando apresentava altura média de $1,80 \mathrm{~m}$ e 80 dias de crescimento. Imediatamente, foi picado em partículas de aproximadamente $5 \mathrm{~cm}$ em máquina ensiladeira acoplada a trator. A casca de café foi adquirida na região de Barra do Choça, Bahia, em fazenda de atividade cafeicultora, e os farelos de cacau e de mandioca foram adquiridos em local de venda apropriado. Todos os aditivos foram adicionados à forragem recém-picada no nível de 15\% com base na matéria natural. A ensilagem foi realizada em tambores de metal com volume de $200 \mathrm{~L}$. Em cada silo foram colocados $90 \mathrm{~kg}$ da mistura fresca, em densidade de $450 \mathrm{~kg} / \mathrm{m}^{3}$. Após o enchimento, os silos foram vedados com lona plástica por um período de 60 dias (Tabela 1).

Foram utilizados 20 ovinos Santa Inês, machos nãocastrados, com 5 meses de idade e 22,27 $\pm 3,24 \mathrm{~kg}$ de peso

Tabela 1 - Composição bromatológica dos ingredientes das dietas experimentais

\begin{tabular}{|c|c|c|c|c|c|c|}
\hline \multirow[b]{2}{*}{ Item $^{1}$} & \multicolumn{5}{|c|}{ Ingrediente (\%MS) } & \multirow[b]{2}{*}{ Capim-elefante } \\
\hline & Milho & Farelo de soja & Casca de café & Farelo de cacau & Farelo de mandioca & \\
\hline Matéria seca & 86,5 & 88,1 & 89,8 & 86,0 & 88,8 & 28,3 \\
\hline Mistura mineral & 1,6 & 6,6 & 5,6 & 8,8 & 1,5 & 6,0 \\
\hline Proteína bruta & 9,0 & 46,7 & 7,2 & 15,0 & 2,4 & 5,9 \\
\hline Extrato etéreo & 2,8 & 2,4 & 0,8 & 2,6 & 0,8 & 2,3 \\
\hline Hemicelulose & 11,0 & 4,6 & 15,8 & 11,9 & 4,7 & 29,8 \\
\hline Celulose & 2,6 & 6,8 & 41,6 & 17,8 & 4,5 & 36,3 \\
\hline Lignina & 0,4 & 1,0 & 16,1 & 15,6 & 1,0 & 5,4 \\
\hline Carboidratos totais & 86,6 & 44,3 & 86,4 & 73,6 & 95,2 & 85,8 \\
\hline Carbohidratos não-fibrosos & 75,5 & 34,3 & 18,3 & 39,6 & 92,4 & 17,1 \\
\hline NIDN/NT & 16,0 & 3,0 & 52,3 & 44,2 & 6,9 & 22,2 \\
\hline
\end{tabular}

${ }^{1}$ NIDN: nitrogênio insolúvel em detergente neutro (porcentual do nitrogênio total); NIDA: nitrogênio insolúvel em detergente ácido (porcentual do nitrogênio total); NDTest: nutrientes digestíveis totais estimados (NRC, 2001). 
corporal, distribuídos em delineamento inteiramente casualizado, com cinco repetições. Os animais foram mantidos em baias individuais de $1,3 \times 0,65 \mathrm{~m}\left(0,84 \mathrm{~m}^{2}\right)$, com piso suspenso, ripado de madeira, com bebedouros e comedouros individuais, por 77 dias (14 dias de adaptação e três períodos de 21 dias para coleta de dados).

As dietas foram formuladas com milho, farelo de soja e mistura mineral para serem isoprotéicas (Tabela 3) e compostas de $60 \%$ de silagem de capim-elefante, com ou sem aditivos, e 40\% de concentrado, com base na matéria seca (Tabela 2), conforme os seguintes tratamentos: capimelefante ensilado sem aditivo + concentrado; capim-elefante ensilado com 15\% de casca de café + concentrado; capimelefante ensilado com 15\% de farelo de cacau + concentrado; capim-elefante ensilado com 15\% de farelo de mandioca + concentrado.

Ao início do experimento, os animais foram vermifugados, pesados, identificados com brincos numerados e sorteados ao acaso entre as dietas. As pesagens foram realizadas a cada 21 dias, do início do experimento até o peso de abate. Para a pesagem do final do período de adaptação e final do experimento, os animais foram submetidos a jejum de líquidos e sólidos por 14 horas.

A mistura entre o volumoso e o concentrado foi realizada no momento do fornecimento da alimentação. Os animais foram alimentados à vontade, às $7 \mathrm{~h}$ e às $16 \mathrm{~h}$, por meio da pesagem do fornecido e das sobras, admitindo $10 \%$ de sobras.

Tabela 2 - Composição percentual das dietas experimentais, com base na matéria seca (MS)

\begin{tabular}{|c|c|c|c|c|}
\hline \multirow[t]{2}{*}{ Ingrediente } & \multicolumn{4}{|c|}{ Silagem de capim-elefante } \\
\hline & Sem aditivo & $\begin{array}{l}\text { Com } 15 \% \text { de } \\
\text { casca de café }\end{array}$ & $\begin{array}{l}\text { Com } 15 \% \text { de } \\
\text { farelo de cacau }\end{array}$ & $\begin{array}{l}\text { Com } 15 \% \text { de } \\
\text { farelo de mandioca }\end{array}$ \\
\hline Silagem de capim-elefante & 60,0 & 53,7 & 53,7 & 52,8 \\
\hline Casca de café & 0,0 & 6,3 & 0,0 & 0,0 \\
\hline Farelo de cacau & 0,0 & 0,0 & 6,3 & 0,0 \\
\hline Farelo de mandioca & 0,0 & 0,0 & 0,0 & 7,2 \\
\hline Milho moído & 25,0 & 27,0 & 27,5 & 24,5 \\
\hline Farelo de soja & 12,0 & 10,0 & 9,5 & 12,5 \\
\hline Mistura mineral & 3,0 & 3,0 & 3,0 & 3,0 \\
\hline Total & 100 & 100 & 100 & 100 \\
\hline
\end{tabular}

Tabela 3 - Composição química dos volumosos e das dietas experimentais, com base na matéria seca

\begin{tabular}{|c|c|c|c|c|}
\hline \multirow[t]{2}{*}{ Composição do volumoso $(\%)^{1}$} & \multicolumn{4}{|c|}{ Silagem de capim-elefante } \\
\hline & Sem aditivo & $\begin{array}{l}\text { Com } 15 \% \text { de } \\
\text { casca de café }\end{array}$ & $\begin{array}{l}\text { Com } 15 \% \text { de } \\
\text { farelo de cacau }\end{array}$ & $\begin{array}{l}\text { Com } 15 \% \text { de } \\
\text { farelo de mandioca }\end{array}$ \\
\hline Matéria seca & 31,4 & 34,7 & 35,1 & 35,4 \\
\hline Proteína bruta & 4,5 & 5,8 & 7,8 & 4,5 \\
\hline Extrato etéreo & 3,3 & 3,2 & 4,5 & 2,6 \\
\hline Fibra em detergente neutro & 78,9 & 79,0 & 70,8 & 65,7 \\
\hline Fibra em detergente ácido & 46,7 & 52,1 & 45,1 & 34,9 \\
\hline Carboidratos totais & 85,9 & 84,4 & 81,1 & 87,3 \\
\hline Carboidratos não-fibrosos & 10,8 & 10,7 & 16,8 & 26,1 \\
\hline Proteína insolúvel em detergente neutro $(\% \mathrm{~PB})^{2}$ & 22,8 & 38,6 & 44,2 & 27,2 \\
\hline Nutrientes digestíveis totais estimados ${ }^{3}$ & 49,1 & 40,3 & 42,6 & 58,8 \\
\hline \multicolumn{5}{|l|}{ Nutrientes na dieta $(\%)^{1}$} \\
\hline Matéria seca & 54,0 & 56,1 & 56,3 & 56,2 \\
\hline Proteína bruta & 10,7 & 10,4 & 11,9 & 11,1 \\
\hline Extrato etéreo & 3,1 & 3,2 & 3,4 & 2,9 \\
\hline Fibra em detergente neutro & 52,3 & 52,8 & 47,7 & 44,9 \\
\hline Fibra em detergente ácido & 32,3 & 34,5 & 29,6 & 24,8 \\
\hline Carboidratos totais & 78,5 & 79,0 & 76,6 & 78,7 \\
\hline Carboidratos não-fibrosos & 30,0 & 31,5 & 35,3 & 39,2 \\
\hline Proteína insolúvel em detergente neutro $(\% \mathrm{~PB})^{2}$ & 16,3 & 26,1 & 29,5 & 18,5 \\
\hline Nutrientes digestíveis totais estimados ${ }^{3}$ & 64,6 & 59,4 & 60,8 & 70,6 \\
\hline
\end{tabular}

\footnotetext{
${ }^{1}$ Dados obtidos por meio de análise química.

2 Proteína insolúvel em detergente neutro/percentual da proteína bruta.
}

3 Nutrientes digestíveis totais estimados (NRC, 2001). 
Amostras dos alimentos fornecidos e das sobras foram coletadas diariamente, formando uma mistura composta por animal, que foi acondicionada em freezer a $-10^{\circ} \mathrm{C}$. Posteriormente, a cada 21 dias, as amostras foram homogeneizadas e uma alíquota referente a cada animal foi retirada para posteriores análises químicas. As amostras foram pré-secas em estufa de ventilação forçada a $60^{\circ} \mathrm{C}$, durante 72 horas, e, em seguida, foram trituradas em moinho tipo Willey, utilizando-se peneira de $1 \mathrm{~mm}$.

As análises de matéria seca (MS), matéria orgânica (MO), nitrogênio total (NT), extrato etéreo (EE), fibra em detergente neutro (FDN), fibra em detergente ácido (FDA); e a determinação dos teores de nitrogênio insolúvel em detergente neutro (NIDN) e nitrogênio insolúvel em detergente ácido (NIDA), expressos em porcentagem do nitrogênio total, foram realizadas segundo procedimentos descritos por Silva \& Queiroz (2002). O teor de proteína bruta (PB) foi obtido multiplicando-se o nitrogênio total pelo fator 6,25. O teor de carboidratos totais (CT) foi calculado segundo equações propostas por Sniffen et al. (1992), em que $\mathrm{CT}=100$ - (\%PB + \%EE + \%Cinzas), enquanto os teores de carboidratos não-fibrosos (CNF) foram obtidos pela fórmula $\mathrm{CNF}=\mathrm{CT}-\mathrm{FDN}_{\mathrm{cp}}$.

Os teores de nutrientes digestíveis totais estimados $\left(\mathrm{NDT}_{\mathrm{EST}}\right)$ dos alimentos, dos concentrados e das dietas totais foram calculados conforme equações descritas pelo

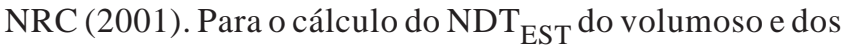
resíduos, foi utilizada a equação: $\mathrm{NDT}_{\mathrm{EST}}=0,98$ [100 $\left(\% \mathrm{FDN}_{\mathrm{p}}+\% \mathrm{~PB}+\% \mathrm{EE}+\%\right.$ cinza $\left.) \times \mathrm{PF}\right]+\mathrm{PB} \times \exp [-1,2 \times$ $(\mathrm{PIDA} / \mathrm{PB})]+2,25 \times(\mathrm{EE}-1)+0,75 \times\left(\mathrm{FDN}_{\mathrm{p}}-\right.$ Lignina $) \times[1-$ $\left(\text { Lignina/FDN }{ }_{\mathrm{p}}\right)^{0,667}$ ] -7 e, para o cálculo do $\mathrm{NDT}_{\mathrm{EST}}$ dos concentrados, a equação: $\mathrm{NDT}_{\mathrm{EST}}=0,98\left[100-\left(\% \mathrm{FDN}_{\mathrm{p}}+\right.\right.$ $\% \mathrm{~PB}+\% \mathrm{EE}+\%$ cinza $) \times \mathrm{PF}]+\mathrm{PB} \times \exp [-0,4 \times(\mathrm{PIDA} / \mathrm{PB})]$ $+2,25 \times(\mathrm{EE}-1)+0,75 \times\left(\mathrm{FDN}_{\mathrm{p}}\right.$ - lignina $) \times[1$ - (lignina/ $\left.\left.\mathrm{FDN}_{\mathrm{p}}\right)^{0,667}\right]-7$, em que, nas equações anteriores:

$\mathrm{FDN}_{\mathrm{p}}=\mathrm{FDN}-\mathrm{PIDN}(\mathrm{PIDN}=$ nitrogênio insolúvel em detergente neutro $\times 6,25$ )

$\mathrm{PF}=$ efeito do processamento físico na digestibilidade dos carboidratos não-fibrosos

PIDA = nitrogênio insolúvel em detergente ácido $\times 6,25$

Para valores de $\mathrm{EE}<1$, na equação $(\mathrm{EE}-1)=0$.

Os resultados foram submetidos à análise de variância e ao teste Tukey, adotando-se o nível de significância de 5\%, utilizando-se o programa Sistema de Análises Estatísticas e Genéticas - SAEG (UFV, 1998).

\section{Resultados e Discussão}

O consumo de matéria seca da silagem de capim-elefante com $15 \%$ de farelo de mandioca, independentemente da forma como expresso, foi superior $(\mathrm{P}<0,05)$ ao da silagem sem aditivo, porém não diferiu $(\mathrm{P}>0,05)$ do obtido com a silagem com $15 \%$ de casca de café e com aquela contendo 15\% de farelo de cacau (Tabela 4).

O maior consumo de matéria seca (1.000,4 g/dia) pelos ovinos alimentados com silagem contendo $15 \%$ de farelo de mandioca pode ser explicado pelo menor teor de FDN da dieta $(44,9 \%)$, enquanto a dieta contendo casca de café apresentou maior teor de FDN (52,8\%) e menor consumo de matéria seca, corroborando observações descritas por Mertens (1992), que afirmou que a FDN é um dos principais fatores de controle do consumo de matéria seca.

Os valores encontrados para consumo de matéria seca em \% PC (3,8\%) e g/kg $0075 /$ dia $\left(86,9\right.$ g/ $\mathrm{kg}^{0,75} /$ dia) para silagem com farelo de mandioca foram superiores aos verificados por Zeoula et al. (2003) em ovinos mantidos com dietas com 25, 50, 75 e 100\% de farinha de varredura de mandioca (Manihot esculenta), 2,9\% PC e 74,8 g/ $\mathrm{kg}^{0,75} / \mathrm{dia}$, em substituição ao milho. O consumo de matéria seca encontrado neste trabalho, de 79,8 g/ $\mathrm{kg}^{0,75} / \mathrm{dia}$, para a silagem com casca de café foi semelhante ao obtido por Garcia et al. (2000), de 76,0 g/ $/ \mathrm{kg}^{0,75} / \mathrm{dia}$, usando casca de café no nível de $15 \%$ do concentrado padrão (milho e soja). Apesar das pequenas variações observadas, o consumo de matéria seca verificado neste trabalho é considerado satisfatório e está de acordo com os valores observados na literatura.

O consumo de proteína bruta $(\mathrm{P}<0,05)$ foi maior nos animais alimentados com as rações com farelo de cacau e farelo de mandioca, 120,0 e 121,2 g, respectivamente. Como as dietas foram formuladas para serem isoprotéicas, o maior consumo de matéria seca, associado ao maior percentual de PB (11,9 e 11,1\%), pode explicar a diferença da ingestão de proteína bruta.

A ingestão de proteína bruta (Tabela 4), para todas as dietas, foi inferior à preconizada pelo NRC (1985), que recomenda ingestão diária de 12,25 g/ $/ \mathrm{kg}^{0,75}$ (137 g de PB para $25 \mathrm{~kg}$ de $\mathrm{PC}$ ) para ganho de peso de $150 \mathrm{~g} /$ dia em ovinos com $25 \mathrm{~kg}$ de PC.

Pires et al. (2004), avaliando níveis de 0 e $30 \%$ de farelo de cacau em substituição ao milho e farelo de soja na alimentação de ovinos, verificaram consumo de proteína bruta de $87,14 \mathrm{~g} /$ dia nos animais que receberam o farelo de cacau, inferior ao encontrado neste trabalho, de $120 \mathrm{~g} /$ dia, para a silagem contendo farelo de cacau. Esses autores limitaram o fornecimento de concentrado a $400 \mathrm{~g} / \mathrm{animal} /$ dia e utilizaram a silagem de sorgo com 7,29\% de PB, possíveis fatores que determinaram diferenças no consumo de proteína bruta. Oliveira (2005) verificou efeito linear decrescente dos níveis de farelo de 
Tabela 4 - Consumo médio diário de nutrientes em ovinos alimentados com rações com capim-elefante ensilado com diferentes aditivos ${ }^{1}$

\begin{tabular}{|c|c|c|c|c|c|c|}
\hline \multirow[t]{2}{*}{ Item } & \multicolumn{4}{|c|}{ Silagem de capim-elefante } & \multirow[t]{2}{*}{ Média } & \multirow[t]{2}{*}{$\mathrm{CV}^{2}$} \\
\hline & Sem aditivo & $\begin{array}{l}\text { Com } 15 \% \text { de } \\
\text { casca de café }\end{array}$ & $\begin{array}{l}\text { Com } 15 \% \text { de } \\
\text { farelo de cacau }\end{array}$ & $\begin{array}{l}\text { Com } 15 \% \text { de } \\
\text { farelo de mandioca }\end{array}$ & & \\
\hline \multicolumn{7}{|c|}{ Consumo de matéria seca } \\
\hline g/dia & $762,7 \mathrm{~b}$ & $875,8 \mathrm{ab}$ & $958,5 \mathrm{ab}$ & $1000,4 \mathrm{a}$ & 899,4 & 12,1 \\
\hline$\%$ PC & 3,31b & 3,59ab & 3,73ab & $3,85 a$ & 3,6 & 7,7 \\
\hline $\mathrm{g} / \mathrm{kg}^{0,75}$ & $72,4 b$ & $79,8 a b$ & $83,9 a$ & $86,9 \mathrm{a}$ & 80,7 & 7,1 \\
\hline \multicolumn{7}{|c|}{ Consumo de proteína bruta } \\
\hline g/dia & $88,4 b$ & $91,0 \mathrm{~b}$ & $120,0 \mathrm{a}$ & $121,2 \mathrm{a}$ & 105,1 & 10,0 \\
\hline$\% \mathrm{PC}$ & $0,38 b$ & $0,39 b$ & $0,47 \mathrm{a}$ & $0,47 a$ & 0,43 & 6,9 \\
\hline $\mathrm{g} / \mathrm{kg}^{0,75}$ & $8,4 \mathrm{~b}$ & $8,6 b$ & $10,5 \mathrm{a}$ & $10,5 \mathrm{a}$ & 9,5 & 5,6 \\
\hline \multicolumn{7}{|c|}{ Consumo de fibra em detergente neutro } \\
\hline g/dia & $368,9 a$ & $405,8 a$ & $430,9 a$ & $404,7 a$ & 402,6 & 11,9 \\
\hline$\%$ PC & $1,60 \mathrm{a}$ & $1,74 \mathrm{a}$ & $1,68 \mathrm{a}$ & $1,56 \mathrm{a}$ & 1,64 & 8,5 \\
\hline $\mathrm{g} / \mathrm{kg}^{0,75}$ & $35,0 \mathrm{a}$ & $38,2 \mathrm{a}$ & $37,7 a$ & $35,2 \mathrm{a}$ & 36,5 & 7,9 \\
\hline \multicolumn{7}{|c|}{ Consumo de fibra em detergente ácido } \\
\hline g/dia & $212,2 b$ & $257,6 a b$ & $269,1 \mathrm{a}$ & $205,9 b$ & 236,2 & 12,5 \\
\hline$\%$ PC & $0,92 \mathrm{bc}$ & $1,10 \mathrm{a}$ & $1,04 \mathrm{ab}$ & $0,80 \mathrm{c}$ & 0,97 & 8,4 \\
\hline $\mathrm{g} / \mathrm{kg}^{0,75}$ & $20,1 b$ & $24,3 a$ & $23,5 a$ & $17,9 b$ & 21,5 & 7,9 \\
\hline \multicolumn{7}{|c|}{ Consumo de nutrientes digestíveis totais } \\
\hline g/dia & $514,1 b$ & $542,2 b$ & $593,9 b$ & $736,9 a$ & 596,8 & 11,4 \\
\hline$\%$ PC & $2,23 b$ & $2,23 \mathrm{~b}$ & $2,31 b$ & $2,84 a$ & 2,40 & 7,6 \\
\hline $\mathrm{g} / \mathrm{kg}^{0,75}$ & $48,8 b$ & $49,4 b$ & $52,0 \mathrm{~b}$ & $64,0 \mathrm{a}$ & 53,5 & 6,8 \\
\hline
\end{tabular}

${ }^{1}$ Médias seguidas de mesma letra, na linha, não diferem entre si pelo teste de Tukey a 5\% de probabilidade.

2 Coeficiente de variação (\%).

cacau sobre o consumo de proteína bruta (54,0;41,0; 39,0 e 35,0 g/dia) em caprinos.

Os valores obtidos nesta pesquisa (120,0 g/dia) para as silagens com farelo de cacau foram superiores ao relatado por esse autor, independentemente da redução. Os maiores consumos de proteína bruta obtidos neste estudo para as silagens contendo farelo de cacau e farelo de mandioca, 120,0 e 121,2 g/dia, respectivamente, foram similares aos encontrados por Véras et al. (2005), que verificaram valor médio de 125,0 g de PB/dia para ovinos SRD (sem raça definida) alimentados com níveis 0, 33, 66 e 100\% de palma forrageira em substituição ao milho. Entretanto, apesar da semelhança dos resultados, deve-se considerar que a palma forrageira apresenta alta aceitabilidade e alta taxa de degradação ruminal, diferentemente do farelo de cacau, uma vez que o maior teor de proteína bruta (18\%) da dieta experimental utilizada pelos autores pode influenciar o maior consumo de PB.

Silva et al. (2005), alimentando cabras Saanen em lactação com rações contendo 0, 15 e 30\% de farelo de cacau em substituição ao concentrado padrão (milho + soja), observaram consumos de 293,96; 299,91 e 180,68 g/dia de $\mathrm{PB}$, o que comprova redução no consumo de proteína bruta apenas no nível de 30\% de farelo de cacau. Como esses autores utilizaram maior teor de PB $(13,5 \%)$ e maior proporção de concentrado (64\% na MS), possivelmente essas diferenças foram responsáveis pelas diferenças de consumo.

Os valores referentes ao consumo de fibra em detergente neutro, expressos em g/dia, \% PC e em g/kg0,75/dia, não diferiram $(\mathrm{P}>0,05)$ entre as dietas (Tabela 4$)$. O consumo de FDN foi superior ao proposto por Van Soest (1994), entre 0,8 e $1,2 \%$ PC, o que pode estar relacionado a uma compensação dos animais, que ingerem maior volume de alimentos para suprir suas necessidades nutricionais, uma vez que o nível de concentrado das dietas foi de $40 \%$. Os valores obtidos foram similares aos verificados por Carvalho et al. (2006), que incluíram 0, 10, 20 e 30\% de farelo de cacau em substituição ao milho e farelo de soja na alimentação de ovinos e não encontraram diferença no consumo de FDN, ou seja, o consumo desta fração não foi afetado pelos níveis utilizados. Da mesma forma, Zeoula et al. (2003), em pesquisa com ovinos, com substituição de 25, 50, 75 e 100\% do milho por farinha de varredura, e Souza et al. (2004), com substituição de 0,0; 6,25; 12,5; 18,75 e 25\% do milho por casca de café no concentrado, não detectaram diferenças no consumo de FDN.

Os valores referentes ao consumo de fibra em detergente ácido (FDA), em todas as unidades observadas, não 
diferiram $(\mathrm{P}>0,05)$ entre as dietas com casca de café e com farelo de cacau e foram superiores $(\mathrm{P}<0,05)$ aos obtidos com as demais dietas (Tabela 4). Os maiores consumos de FDA (g/dia, \% PC e g/kg0,75/dia) podem ser explicados pelo maior teor de FDA na dieta com silagem de capim-elefante e casca de café (34,5\%). O valor obtido neste trabalho para a silagem de capim-elefante com farelo de cacau (269,1 g/dia) foi semelhante ao encontrado por Carvalho et al. (2006), que substituíram o milho e o farelo de soja por farelo de cacau em dietas para ovinos e verificaram consumo crescente de FDA (275,0 g/dia). Sousa (2005) também verificou aumento no consumo de FDA, média de 353,5 g/dia, em ovinos alimentados com rações contendo 0, 7, 14 e 21\% de farelo de cacau no concentrado.

Os animais alimentados com rações contendo silagem de capim-elefante com farelo de mandioca apresentaram ganhos de peso total e diário superiores $(\mathrm{P}<0,05)$ aos obtidos com as demais rações, com médias de $8,85 \mathrm{~kg}$ e 140,5 g, respectivamente (Tabela 5). Esse resultado pode ser explicado pelo maior consumo de nutrientes digestíveis totais (736,9 g/dia) por esses animais (Tabela 4), apesar de inferior ao valor predito pelo NRC (1985), que sugere consumo em torno de 850,0 g de NDT/dia para ganho de $200 \mathrm{~g} / \mathrm{dia}$, em animais $20 \mathrm{~kg}$ peso corporal. De acordo com Mertens (1994) e Van Soest (1994), o animal tende a aumentar o consumo com rações contendo mais baixos níveis de energia para atender seus requisitos, até ocorrer repleção ruminal, que geralmente ocorre em situações de alto consumo de FDN.

O desempenho dos animais neste trabalho parece não ter sido influenciado pelo consumo de matéria seca $\left(80,7 \mathrm{~g} / \mathrm{kg}^{0,75} / \mathrm{dia}\right)$, apesar de ter sido baixo em comparação ao preconizado pelo NRC (1985), de 100 g/ $/ \mathrm{kg}^{0,75} / \mathrm{dia}$. No entanto, em trabalhos semelhantes realizados no Brasil com ovinos Santa Inês na mesma faixa de peso e ingestão de MS, são relatados ganhos de peso maiores (Alves et al., 2003; Furusho-Garcia et al., 2004). O menor desempenho observado neste trabalho pode ser atribuído à relação proteína:energia, que afeta a conversão alimentar dos animais (Zundt et al., 2002), ao baixo valor nutritivo da silagem (\% PB) e alta \% de FDN (Tabela 3), associada ao baixo nível de adição de concentrado à dieta (40\%).

O ganho de peso (140,5 g/dia) dos animais alimentados com silagem contendo farelo de mandioca foi superior aos valores encontrados por Pires et al. (2004), 90,45 e 82,99 g/dia, respectivamente, em ovinos 5/8 Santa Inês alimentados com ração contendo 0 e $30 \%$ de farelo de cacau. O resultado deste estudo foi superior também ao ganho de peso diário observado por Silva et al. (2008) em ovinos Santa Inês alimentados com rações com $40 \%$ de farelo de cacau no concentrado e capim-elefante amonizado e similar aos encontrados por Sousa (2005), média 132,4 g/dia, em pesquisa com ovinos alimentados com rações contendo 0 a $21 \%$ de farelo de cacau na dieta total.

Ganho de peso superior ao obtido neste experimento foi observado por Garcia et al. (2000), que obtiveram média de 199,7 g/dia em cordeiros recebendo dietas com 15\% casca de café no concentrado, tratada ou não com uréia.

A conversão alimentar foi semelhante $(\mathrm{P}>0,05)$ entre as dietas, com média de 9,6, apesar de o consumo de matéria seca ter aumentado com a utilização dos aditivos na silagem de capim-elefante, o que indica que esse maior consumo não refletiu em aumento nos ganhos diários que possibilitassem a melhoria da conversão alimentar. Nos animais alimentados com a silagem de capim-elefante contendo farelo de cacau $(11,6)$, a conversão alimentar foi semelhante à encontrada por Pires et al. (2004), de 12,27 e 12,41, respectivamente, em ovinos alimentados com rações com 0 e 30\% de farelo de cacau. Carvalho et al. (2006) também alimentaram ovinos com rações contendo 0 a $30 \%$ de farelo de cacau em substituição ao milho e ao farelo de soja e obtiveram média de 10,01.

Garcia et al. (2000) alimentaram ovinos confinados com dietas contendo casca de café e obtiveram índice de 6,39 de conversão alimentar. O resultado obtido nesta pesquisa com silagem de capim-elefante com casca de café foi inferior ao descrito por esses autores, também com silagem de capim-elefante.

Tabela 5 - Desempenho de ovinos alimentados com rações contendo capim-elefante ensilado com diferentes aditivos ${ }^{1}$

\begin{tabular}{lccccc}
\hline Variável & \multicolumn{3}{c}{ Silagem de capim-elefante } & \multirow{2}{*}{ Média $^{\text {CV }^{2}}$} \\
\cline { 2 - 4 } & Sem aditivo & $\begin{array}{c}\text { Com 15\% de } \\
\text { casca de café }\end{array}$ & $\begin{array}{c}\text { Com 15\% de } \\
\text { farelo de cacau }\end{array}$ & $\begin{array}{c}\text { Com 15\% de } \\
\text { farelo de mandioca }\end{array}$ & \\
\hline Peso inicial & 21,3 & 22,0 & 22,9 & 22,9 & 22,3 \\
Peso final & 27,1 & 27,6 & 28,7 & 31,0 & 28,6 \\
Ganho de peso total $(\mathrm{kg})$ & $5,45 \mathrm{~b}$ & $6,33 \mathrm{~b}$ & $5,80 \mathrm{~b}$ & $8,85 \mathrm{a}$ & 6,61 \\
Ganho de peso diário $(\mathrm{g})$ & $86,5 \mathrm{~b}$ & $100,4 \mathrm{~b}$ & $92,1 \mathrm{~b}$ & $140,5 \mathrm{a}$ & 20,0 \\
Conversão alimentar & $9,3 \mathrm{a}$ & $9,8 \mathrm{a}$ & $11,6 \mathrm{a}$ & $7,5 \mathrm{a}$ & 104,9 \\
\hline
\end{tabular}

${ }^{1}$ Médias seguidas de mesma letra, na linha, não diferem entre si pelo teste Tukey a 5\% de probabilidade.

2 Coeficiente de variação (\%). 


\section{Conclusões}

A casca de café, o farelo de cacau e o farelo de mandioca, quando utilizados no nível de 15\% da matéria natural, melhoram o consumo de matéria seca da silagem de capim-elefante. A silagem de capim-elefante com farelo de mandioca proporciona melhor consumo de nutrientes digestíveis totais. O capim-elefante ensilado com $15 \%$ de farelo de mandioca proporciona melhor desempenho em ovinos Santa Inês. A utilização de farelo de mandioca na silagem de capim-elefante é uma alternativa viável na formulação de dietas para ovinos.

\section{Literatura Citada}

ANDRADE, J.B.; LAVEZZO, W. Aditivos na ensilagem do capimelefante. I. Composição bromatológica das forragens e das respectivas silagens. Pesquisa Agropecuária Brasileira, v.33, n.11, p.1859-1872, 1998.

ALVES, K.S.; CARVALHO, F.F.R.; VÉRAS, A.S.C. et al. Níveis de energia em dietas para ovinos Santa Inês: desempenho. Revista Brasileira de Zootecnia, v.32, n.6, p.1937-1944, 2003 (supl 2).

CARVALHO, G.G.P.; PIRES, A.J.V.; VELOSO, C.M. et al. Desempenho e digestibilidade de ovinos alimentados com farelo de cacau (Theobroma cacao L.) em diferentes níveis de substituição. Ciência Animal Brasileira, v.7, n.2, p.115-122, 2006.

FURUSHO-GARCIA, I.F.; PEREZ, J.R.O.; BONABURIO, S. et al. Desempenho de cordeiros Santa Inês puros e cruzas Santa Inês com Texel, Ilhe de France e Berganácia. Revista Brasileira de Zootecnia, v.33, n.6, p1591-1603, 2004.

GARCIA, I.F.F.; PEREZ, J.R.O.; OLIVEIRA, M.V. et al. Características de carcaça de cordeiros Texel x Bergamácia, Texel $x$ Santa Inês e Santa Inês puros, terminados em confinamento, com casca de café como parte da dieta. Revista Brasileira de Zootecnia, v.29, n.1, p.253-260, 2000.

LAVEZZO, W. Ensilagem do capim-elefante. In: SIMPÓSIO SOBRE MANEJO DA PASTAGEM, 10., 1993, Piracicaba. Anais... Piracicaba: Fundação de Estudos Agrários "Luis de Queiroz”, 1993. p.169-276.

McDONALD, P. The biochemistry of silage. New York: John Wiley \& Sons, 1981. 207p.

MERTENS, D.R. Regulation of forage intake. In: FAHEY JR., G.C. (Ed.). Forage quality, evaluation and utilization. Madison: American Society of Agronomy, 1994. p.450-493.

MERTENS, D.R. Analysis of fiber in feeds and its uses in feed evaluation and ration formulation. In: SIMPÓSIO INTERNACIONAL DE RUMINANTES, REUNIÃO ANUAL DA SOCIEDADE BRASILEIRA DE ZOOTECNIA, 29., 1992, Lavras. Anais... Lavras: Sociedade Brasileira de Zootecnia, 1992. p.1-32.
NATIONAL RESEARCH COUNCIL - NRC. Nutrient requirements of dairy cattle. 7.ed. Washington: National Academy Press, 2001. 381p.

NATIONAL RESEARCH COUNCIL - NRC. Nutrient requirements of sheep. Washington, D.C.: National Academy Press, 1985. 99p.

OLIVEIRA. A.R.A. Farelo de cacau (Theobroma cacao L.) na alimentação de caprinos em crescimento. 2005. 40f. (Dissertação Mestrado em Zootecnia - Universidade Estadual do Sudoeste da Bahia, Itapetinga, 2005.

PIRES, A.J.V.; CARVALHO JR., J.N.; SILVA, F.F. et al. Farelo de cacau na alimentação de ovinos. Revista Ceres, v.51, n.293, p.33-43, 2004.

SILVA, D.J.; QUEIROZ, A.C. Análise de alimentos: métodos químicos e biológicos. 3.ed. Viçosa, MG: Editora UFV, 2002. 235p.

SILVA, H.G.O.; PIRES, A.J.V.; SILVA, F.F. et al. Farelo de cacau (Theobroma cacao L.) e torta de dendê (Elaeis guineensis, jacq) na alimentação de cabras em lactação: consumo e produção de leite. Revista Brasileira de Zootecnia, v.34, n.5, p.1786-1794, 2005.

SILVA, H.G.O.; PIRES, A.J.V.; CARVALHO, G.G.P. et al. Capimelefante (Pennisetum purpureum Schum.) amonizado, farelo de cacau (Theobroma cacao L.) e torta de dendê (Elaeis guineensis, Jacq) na alimentação de ovinos. Revista Brasileira de Zootecnia, v.37, n.4, p.734-742, 2008.

SNIFFEN, C.J.; O’CONNOR, J.D.; Van SOEST, P.J. et al. A net carbohydtrate and protein system for evaluating cattle diets: II. Carbohydrate and protein availability. Journal of Animal Science, v.70, n.11, p.3562-3577, 1992.

SOUSA, F.G. Níveis crescente de farelo de cacau (Theobroma cacao L.) na alimentação de ovinos. 2005. 60f. (Dissertação Mestrado em Agronomia - Universidade Estadual do Sudoeste da Bahia, Vitória da Conquista, 2005.

SOUZA, A.L.; BERNARDINO, F.S.; GARCIA, R. et al. Casca de café em dietas de carneiros: consumo e digestibilidade. Revista Brasileira de Zootecnia, v.33, n.6, p.2170-2176, 2004 (supl. 1).

UNIVERSIDADE FEDERAL DE VIÇOSA - UFV. Sistema de análises estatístico e genéticas - SAEG. versão 8.0. Viçosa, MG: Fundação Arthur Bernardes, 1998. (CD-ROM).

Van SOEST, P.J. Nutritional ecology of the ruminants. 2.ed. Ithaca: Cornell University Press, 1994. 476p.

VÉRAS, R.M.L.; FERREIRA, M.A.; VÉRAS, A.S.C. et al. Substituição do milho por farelo de palma forrageira em dietas para ovinos em crescimento: consumo e digestibilidade. Revista Brasileira de Zootecnia, v.34, n.1, p.351-356, 2005.

ZEOULA, L.M.; CALDAS NETO, S.F.; GERON, L.J.V. et al. Substituição do milho pela farinha de varredura de mandioca (Manihot esculenta Crantz) em rações de ovinos: consumo, digestibilidade, balanços de nitrogênio e energia e parâmetros ruminais. Revista Brasileira de Zootecnia, v.32, n.2, p.491-502, 2003.

ZUNDT, M.; MACEDO, F.A.F.; MARTINS, E.N. et al. Desempenho de cordeiros alimentados com diferentes níveis protéicos. Revista Brasileira de Zootecnia, v.31, n.3, p.1307-1314, 2002. 